\title{
As expedições de Karl von den Steinen ao Xingu eos registros inéditos (desde 1893) daviagem de Cuiabá a Coxim
}

\author{
Ely Carneiro de Paiva*
}

O explorador alemão Karl Von den Steinen é considerado o iniciador da investigação científica dos povos indígenas da América do Sul no final do século XIX. De suas duas expedições deixou importantes relatos sobre etnologia, etnografia, geografia e linguística. Sobre a sua segunda expedição existe um registro de Peter Vogel, praticamente desconhecido do meio acadêmico brasileiro. Por gentileza do autor, este relato vem à luz na seção "Caderno Especial".

Palavras-Chave: Século XIX, Expedições, Índios.

German explorer Karl Von den Steinen is considered the initiator of scientific research of the indigenous peoples of South America in the late nineteenth century. From his two expeditions he left important reports on ethnology, ethnography, geography and linguistics. About his second expedition there is a record from Peter Vogel, practically unknown to the Brazilian academy. By the author's kindness, this report comes to light in the "Caderno Especial" section.

Keywords: nineteenth century, expeditions, Indians.

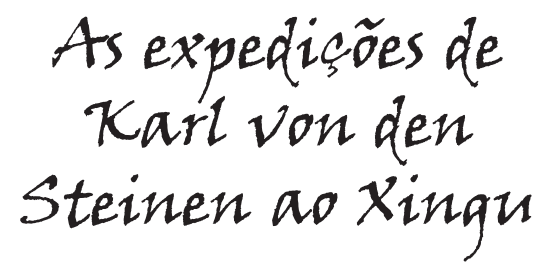

Ama ! - (Tu !)

Ura! - (Eu !)

A ssim se apresentavam duas pessoas na língua dos índios Bacairis do Alto Xingu. Com essas palavras começa um dos mais importantes livros já escritos sobre os índios brasileiros, "Unter den Naturvölkern Zentral-Brasiliens" ("Entre os aborígenes do Brasil Central”), de autoria do etnólogo alemão, Karl von den

\footnotetext{
${ }^{1}$ Engenheiro Eletricista pela Universidade Federal de Uberlândia (UFU) e Doutor pela FEECUNICAMP. Atualmente é Professor da Faculdade de Engenharia Mecânica da Unicamp (FEMUNICAMP), e associado-correspondente do Instituto Histórico e Geográfico do Mato Grosso do Sul (IHGMS). elypaivacarneiro@gmail.com
} 
Steinen (1855-1929), que foi o primeiro estudioso a visitar e documentar essa região particular do Brasil Central ${ }^{1}$.

Karl von den Steinen é considerado o iniciador da investigação científica dos povos indígenas da América do Sul, reformador dos métodos de investigação, e pioneiro e propulsionador da etnologia brasileira, segundo Vera Penteado Coelho na obra de referência sobre o assunto: "Um Século de Antropologia no $X i n g u$ ”2. Além de grande etnólogo e etnógrafo, Steinen se consagrou também como excelente escritor, geógrafo, linguista e naturalista, projeção que obteve após as duas viagens que empreendeu ao Brasil no final do século XIX, uma em 1884 e outra em 1887/1888 com o objetivo de estudar os povos do Brasil Central, até então totalmente desconhecidos.

Médico aos vinte anos de idade, com especialização em Psiquiatria pela Universidade de Berlim, von den Steinen empreendeu a partir de 1879 diversas viagens exploratórias ao redor do mundo, numa das quais se encontrou com seu mestre, Dr. Bastian Berlin, fundador do Museu de Etnologia de Berlim, que o desafiou a "tarefas altas e raras". Tratava-se de estudar os povos "primitivos" do Xingu, em seu estado de isolamento, para coletar o maior número de informações e subsídios para confirmar a sua teoria de evolucionismo social sobre a multiplicação das manifestações culturais dos povos.

Aceitando o desafio que mudaria sua vida, Karl von den Steinen desembarcou em setembro de 1883 em Montevidéu, acompanhado do físico e astrônomo Otto Clauss. Lá os aguardava seu primo Wilhelm von den Steinen, pintor e desenhista. Iniciava-se assim a primeira expedição ao Xingu. Seguiram para Buenos Aires e depois Cuiabá, onde ficaram por cerca de dois meses antes de iniciar o desafio. Ali foram recebidos como os "engenheiros" que iriam investigar as possibilidades de comunicação de Mato Grosso com o Pará, por água ou terra, o que muito ajudaria na exportação de gado para o Amazonas. Posteriormente, porém, essa ambição se mostraria inviável já que o Xingu não oferecia condições de navegação, e o terreno acidentado impossibilitava a construção de ferrovias.

\footnotetext{
${ }^{1}$ STEINEN, Karl Von de. Entre os aborígenes do Brasil Central. Trad. de Egon Schaden. Separata renumerada da "Revista do Arquivo”. N. XXXIV a LVIII. São Paulo: Dep. de Cultura, 1940.

${ }^{2}$ COELHO, Vera Penteado. Um século de antropoligia no Xingu. São Paulo: Edusp/Fapesp, 1943.
} 
A caravana partiu de Cuiabá em 26 de maio de 1884 contando com 38 pessoas, incluindo 4 experientes sertanistas locais, um dos quais era um Bacairi "manso", chamado Antonio Kuikare, que teria um papel fundamental durante toda a viagem ${ }^{3}$. As primeiras aldeias contatadas eram habitadas por Bacairis, e Antonio como intérprete e guia amigável foi um elo seguro e imprescindível.

Durante seis semanas marcharam pelo cerrado despovoado, até atingirem em 13 de Julho o primeiro grande rio das cabeceiras do Xingu, ao qual deram o nome de Rio Batovi em homenagem ao Presidente da Província, Barão de Batovi ${ }^{4}$. A partir daí, durante dois meses e meio navegaram nas águas do Xingu, cheia de incontáveis cataratas e corredeiras, contatando várias etnias diferentes ao longo do percurso. Enfrentaram toda sorte de perigos como doenças (todos contraíram malária), fome e hostilidades, mas como havia dito a seu amigo Bastian em uma carta, "me disponho a empregar todas as forças até o último extremo, por se tratar de uma tarefa tão grande e bela". Atingiram o Porto Moz, em 29 de outubro de 1884, embarcando num barco a vapor rumo ao Pará, e de lá, num transatlântico para o Rio de Janeiro.

Essa primeira expedição de Karl von den Steinen concretizou também um marco geográfico espetacular que foi a determinação das nascentes do rio Xingu pelo $15^{\circ}$ paralelo sul. Além disso, a expedição navegou-o por toda a sua extensão pela primeira vez na história, já que todas as tentativas anteriores partiam da desembocadura do rio e nunca haviam ultrapassado o $4^{\circ}$ paralelo sul. O feito inédito foi questionado na época pelo engenheiro e militar Francisco Antonio Pimenta Bueno que afirmava que o rio Xingu já havia sido navegado no início do século XIX, apresentando cópias de mapas antigos que justifica-

\footnotetext{
${ }^{3}$ Von den Steinen conta que Antonio se prontificou a acompanhá-los e que "tendo podido assim ser fotografado no Rio, devo chamar a atenção do leitor para o retrato do mesmo, aqui estampado, como a imagem de um legítimo índio bacairí”. A versão que é contada por uma bisneta de Antonio, Dona Bili, é entretanto diferente (LAMEGO, 2006). Segundo ela, os cientistas pressionaram para que um Bacairi os acompanhasse, alegando, inclusive, que a expedição tinha o aval do Imperador. Assim, os Bacairis, a fim de se protegerem daqueles gentios e do Governo, se viram obrigados a "sacrificar" Antonio, por ser solteiro e ainda manco de uma perna. Achavam que ele não voltaria, mas Antonio, milagrosamente, sobreviveu.
}

${ }^{4}$ COELHO, Vera Penteado. Op. cit. 
vam a sua opinião. O pesquisador Sergio Nunes Pereira fala da réplica de Karl von den Steinen:

O questionamento de Pimenta Bueno não ficaria sem resposta por parte de von den Steinen. Em março de 1887, pouco antes de iniciar sua segunda viagem ao Xingu, ele comparece à Sociedade de Geografia do Rio de Janeiro a fim de anunciar os objetivos da nova empreitada e reafirmar os resultados da anterior. Nessa ocasião, apresenta novos mapas em substituição ao plano traçado em 1884, a partir dos quais refuta qualquer analogia com a carta de Mato Grosso de 1802, apresentada por Pimenta Bueno. Para além de reacender a "guerra dos mapas", essa atitude inaugura uma nova dimensão no debate com Pimenta Bueno. Segundo von den Steinen, "os mapas antigos, feitos sem instrumentos científicos, talvez tenham um valor grande para a história do país; para a geografia não tem nenhum. Quer sejam bons, quer sejam ruins, é preciso viajar, fazer observações e renunciar a construções teóricas"s.

O planejamento da segunda expedição de 1887/1888, curiosamente foi idealizado já durante a primeira viagem de 1884, no momento em que foi visitada a temida tribo dos Suiás. Após um primeiro contato, marcado por desconfiança mútua, uma relação amigável foi estabelecida, e em uma dessas visitas, um velho cacique desenhou um mapa na areia, indicando com grãos de milho jogados ao chão, a localização de outras nove tribos que residiam nas cabeceiras do Xingu. $\mathrm{Na}$ impossibilidade de visitá-las naquele momento, a segunda viagem se esboçava assim para um futuro próximo.

Os resultados dessa primeira expedição foram registrados por von den Steinen no livro Durch Central-Brasilien - Expedition zur Erforschung des Schingú im Jahre 1884 - Geschichtliches über den Schingú, traduzido para o português por Catarina Baratz Cannabrava em "O Brasil Central", Editora Nacional, São Paulo ${ }^{6}$.

\footnotetext{
${ }^{5}$ PEREIRA, Sergio Nunes. Obsessões geográficas: viagens, conflitos e saberes no âmbito da Sociedade de Geografia do Rio de Janeiro. Revista da SBHC. Rio de Janeiro, v. 3, n. 2, jul.-dez.2005. p.112-124.

${ }^{6}$ STEINEN, Karl Von de. O Brasil Central: expedição em 1884 para a exploração do rio Xingu. Trad. de Catarina Barata Canabrava. São Paulo: Nacional, 1942.
} 


\section{A segunda expedição as Xingu}

Os importantes estudos lingüísticos realizados pelo cientista alemão durante a primeira expedição possibilitaram a classificação das etnias indígenas em quatro grandes grupos, permitindo também determinar as relações de parentescos entre as tribos dessa região e outras do restante do país e até mesmo do Caribe. Mas a coleta de material (cerâmicas, máscaras, utensílios e ferramentas) da primeira expedição havia sido muito escassa. Além disso, era necessário visitar as aldeias apontadas pelo cacique Suiá. Assim se concretizava a segunda viagem ao Xingu.

$\mathrm{Na}$ Segunda Expedição tomaram parte, além dos primos von den Stein, o Dr. Paul Ehrenreich, antropólogo, e o Dr. Peter Vogel, físico e geógrafo. A comissão desembarcou no Rio a 20 de fevereiro de 1887 e, após pesquisas no Museu e na Biblioteca Nacional, seguiu para Buenos Aires, onde conti-nuou as investigações no Museu de La Plata. Reembarcou a 17 de junho no navio fluvial Paraná atingindo Cuiabá em julho. No dia 28, deixou a capital em busca do Rio Culiseu nas cabeceiras do Xingu, onde dedicou atenção particular a onze povoados indígenas da região. Após cinco meses de dificuldades e contratempos, agravados com as chuvas estivais, retornou finalmente a Cuiabá ${ }^{7}$.

Do ponto de vista etnológico e linguístico, a viagem pelos rios Culiseu e Culuene (esse último explorado por Peter Vogel e Luiz Perrot) permitiu confirmar o quadro etnológico levantado na primeira viagem, já que as novas tribos visitadas se enquadravam perfeitamente nas famílias linguísticas determinadas em $1884^{8}$.

Um outro resultado de grande importância dessa segunda expedição ao Brasil Central, foi o estudo dos índios Bororos, na colônia indígena de Teresa Cristina, localizada no rio São Lourenço afluente do rio Cuiabá. A colônia recém fundada

\footnotetext{
${ }^{7}$ OBERACKER, Karl Heinrich. A contribuição teuta à formação da nação brasileira. São Paulo: Presença, 1985.

${ }^{8}$ COELHO, Vera Penteado. Op. cit.
} 
por Antônio José Duarte visava a pacificação dos temíveis índios Coroados, uma nação irmã dos Bororos, já pacificados, da Campanha e Cabaçais, às margens do Rio Paraguai ${ }^{9}$. Karl von den Steinen estudou com detalhes a cultura dos índios Bororos, desde os adornos, a indumentária, as técnicas materiais e representações plásticas, até os rituais de magia e de dança. Teve oportunidade de acompanhar de perto inclusive um ritual funerário Bororo que durava cerca de dois meses. Mas ao contrário dos índios do Xingu, von den Steinen encontrou ali uma nação profundamente transformada e corrompida pela dominação do mundo civilizado. Os militares que administravam a colônia, cultivavam nos índios uma perigosa condição de dependência e de submissão. Distribuíam gratuitamente aos indígenas roupas, bebidas alcoólicas e bugigangas em meio a uma grande corrupção, o que causou um sentimento de indignação e de constrangimento ao cientista alemão ${ }^{10}$. Para ilustrar esse fato, podemos citar um texto de seu livro "Entre os Aborígenes do Brasil Central", onde descrevia uma festa ou "serenata" na colônia:

Ainda não me referi aos Bororo. Estes, porém, não faltavam de modo algum, e estavam ali bem a jeito. Vi, pela primeira vez, um soberbo cacique índio desarrolhar uma garrafa de cerveja alemã. A miude, serviam-se eles com prazer do suco de cevada e da cana, tomando muito mais do que podiam suportar. Frequentes vezes, entresachavam com a sua tagarelice os discursos sentimentais, o que a ninguém incomodava, levantavam as suas garrafadas ao tinir dos copos, tocando-as também, e não se cansavam de abraçar-se cordialmente [...] Até à nossa saída, no dia 18 de Abril, não tivemos ocasião de observar que as nossas desfavoráveis primeiras impressões fossem causadas pela ausência do diretor da catequese. Pelo contrário. Duarte (diretor da colônia) ia tomar banho, dava um passeio à olaria, ou fazia cousas semelhantes; no resto do dia, deixava-se ficar no seu quarto, onde também sempre se viam muitos Bororo. Todos esmolavam. Uns ganhavam alguma cousa, outros nada. Bêbados havia sempre entre eles. Para construção do novo edifício, os soldados carregaram paus e folhas de palmeiras, que tinham tirado do mato. Certa vez até alguns Bororo os ajudaram um bocadinho, a troco de cachaça.

Se preguiça e divertimentos por parte dos funcionários e índios eram o objeto da colônia - então esta poderia servir de brilhante modelo ${ }^{11}$.

\footnotetext{
${ }^{9}$ Idem.

${ }^{10}$ STEINEN, Karl Von den. Op. cit., 1940.

${ }^{11}$ Idem.
} 
Os resultados dessa segunda expedição de Karl von den Steinen foram registrados no livro clássico Unter den naturvolkern zentral-brasiliens: reiseschilderung und ergebnisse der zweiten schingu-expedition 18871888, que possui duas edições, uma de 1894 mais científica e outra de 1897 mais popular, seguindo o sucesso da primeira edição. Foi traduzido para o português por Egon Schaden, com o título "Entre os Aborígenes do Brasil Central"12. A respeito dessa obra, Capistrano de Abreu comenta: "Volume ricamente ilustrado, brilhantemente escrito, vigorosamente pensado, em que se discutem assuntos capitais da história primitiva da humanidade: para resumir tudo em uma palavra, a mais opulenta contribuição moder-na sobre quanto importa aos nossos silvícolas"13.

Os resultados dos trabalhos do antropólogo Paul Ehrenreich nessa segunda expedição aparecem em dois artigos da Revista do Museu Paulista que são "Contribuições para a etnologia do Brasil", traduzido por Egon Schaden ${ }^{14}$ e "A segunda expedição alemã ao rio Xingu" ${ }^{15}$.

\section{A viagem de Peter Vogel pelo rio São Lourenço (Cuiabá - Coxim)}

Ainda a respeito dessa segunda viagem de von den Steinen ao Xingu, existe um importante registro, praticamente desconhecido no meio científico brasileiro, que é o artigo escrito pelo Dr. Peter Vogel na Revista da Sociedade Geográfica de Berlin no final do século XIX, chamado "Reisen in Mato Grosso 1887/ 88 (Zweite Schingu-Expedition)”.

Não há referência a esse artigo na obra clássica, já mencionada, de Vera Penteado Coelho intitulada "Karl von den Steinen: Um Século de Antropolo-

\footnotetext{
${ }^{12}$ Idem.

${ }^{13}$ OBERACKER, Karl Heinrich. Op.cit.

${ }^{14}$ EHRENREICH, P. Contribuições para a etnologia do Brasil. Trad. por Egon Schaden. Revista do Museu Paulista. São Paulo, v. 37, 1948, p. 135.

${ }^{15}$ EHRENREICH, P. A segunda expedição alemã ao rio Xingu. Revista do Museu Paulista. São Paulo, v. 16, 1929, p. 135.
} 
gia no Xingu"16. Apenas uma leve menção ao mesmo aparece no livro "As Ciências no Brasil”, onde encontramos ${ }^{17}$ :

Na segunda expedição, Karl von den Steinen voltou ao Xingu, acompanhado, desta feita, por Peter Vogel, que desempenhou importante missão para a geografia. Além de reunir os resultados de suas observações astronômicas, topográficas, magnéticas e meteorológicas, Peter Vogel anexou ao seu trabalho - Reisen in Mato Grosso 1887-1888, um capítulo de L. von Ammon sobre a geologia da região de Lagoinha. O perfil desenhado por Vogel, correspondente ao trecho de Campo Grande ${ }^{18}$ a Cuiabá, ainda hoje constitui exemplo do cuidado com que Peter Vogel se houve sobre o terreno ${ }^{19}$.

Esse artigo diz respeito à contribuição da participação do Dr. Peter Vogel à segunda expedição e é composto de três partes: (I) resultado dos trabalhos de etnografia com os índios Bacairis no rio Culuene; (II) resultados da viagem pelo Rio São Lourenço, de Cuiabá a Coxim, passando pela colônia Teresa Cristina; e (III) resultados das análises meteorológicas e geológicas da região ${ }^{20}$.

A terceira parte do trabalho, relativa aos resultados de meteorologia e geologia aparece citada em um antigo Boletim de Geologia Brasileiro do início do século XX. De forma que as duas primeiras partes do artigo, de numerosas páginas, aparentemente representam um conteúdo inédito em língua portuguesa desde o seu aparecimento em 1893.

Em especial, a segunda parte do artigo possui uma grande importância histórica pois fornece um panorama completo da região de Cuiabá até Coxim, com informações geográficas precisas, inclusive com a latitude/longitude de cada fazenda importante, dados econômicos (produção agrícola, gado, preços de mercadorias), situação das estradas (Goiás, Piquiri), navegação Paraguai-Taquari, os aldeamentos indígenas e a colônia Teresa Cristina. Essa segunda parte é subdividida em quatro tópicos, sendo que um deles trata exclusivamente de Coxim e região, incluindo uma rica descrição da festa do Divino Espírito Santo na cidade.

\footnotetext{
${ }^{16}$ COELHO, Vera Penteado. Op. cit.

${ }^{17}$ AZEVEDO, Fernando de. As ciências no Brasil. Melhoramentos, 1994.

${ }^{18}$ Aqui o autor se confundiu, pois trata-se de Coxim e não Campo Grande.

${ }^{19}$ AZEVEDO, Fernando. Op. cit., p. 392.

${ }^{20}$ LEONARDOS, Othon Henry. Geociências no Brasil: contribuição germânica. Rio de janeiro: Fórum, 1973.
} 
Sobre essa viagem exploratória de Peter Vogel no Rio São Lourenço encontramos um registro de Karl von den Steinen em seu livro "Entre os Aborígenes do Brasil Central":

A 24 de abril (de 1888) chegamos novamente a Cuiabá. Aqui dissol-veu-se a expedição. Vogel já nem havia voltado conosco; já nos deixara em São Lourenço de onde empreendera, a cavalo, em companhia do Capitão Serejo uma jornada exploradora para Santana do Paranaiba, a fim de determinar um caminho, mais curto que o usual, entre esta localidade e a capital. Wilhelm e eu deixamos Cuiabá com o vapor de maio, enquanto Vogel seguiu mais tarde com outro, e Ehrenreich, que ainda tencionava demo-rar-se um ano no Brasil, dirigiu-se por terra para Goiás de onde, acompanhado pelos fiéis camaradas Carlos e Peter, empreendeu sua viagem pelo Araguaia abaixo ${ }^{21}$.

Outra contribuição de extrema importância para a história de Mato Grosso no século XIX é o mapa feito por Peter Vogel, encontrado como anexo no final da revista citada. Apresentado em grande definição (escala 1:500.000), o mapa mostra toda a região entre Cuiabá e Coxim, incluindo a colônia Teresa Cristina e os enormes latifúndios existentes. A título de exemplo, cita-se a Fazenda São Pedro no atual município de Pedro Gomes, visitada por Vogel, o qual afirmava ser uma propriedade de 784.000 hectares, fundada em 1854 e invadida pelos paraguaios em 1865, fato este confirmado pelo Visconde de Taunay ${ }^{22}$. Como a localização em latitude e longitude da sede dessa fazenda, fornecida por ele, corresponde ainda hoje à mesma Fazenda São Pedro indicada no mapa dos municípios do IBGE, 2007, podemos considerá-la como uma das fazendas mais antigas do Mato Grosso do Sul, embora atualmente de extensão consideravelmente menor.

Essa carta geográfica de Peter Vogel é a mais detalhada dessa região do norte de Mato Grosso do Sul no século XIX, desde o aparecimento da "Carta da Província de Mato Grosso" de Pimenta Bueno elaborado em $1880^{23}$, a qual por sua vez teve como base a carta geográfica do Barão do Melgaço de 1868. Aliás, Peter Vogel critica as distorções na carta de Pimenta Bueno, devido aos erros cumulativos da conversão de légua para quilômetro, e também à falta de obser-

\footnotetext{
${ }^{21}$ STEINEN, Karl Von den. Op. cit., 1940.

${ }^{22} \mathrm{O}$ Visconde de Taunay relata a invasão paraguaia na Fazenda São Pedro, de Luis Teodoro da Silva, em vários de seus livros como "Em Mato Grosso Invadido" e "Cartas de Campanha".

${ }^{23}$ BUENO, Francisco Antônio Pimenta. Carta da província de Matto Grosso organizada em 1880. Rio de Janeiro: Biblioteca Nacional, 1887.
} 
vações astronômicas e medidas de altitude. O mapa de Peter Vogel é aparentemente um material inédito no Brasil, pois todos os mapas da Expedição von den Steinen que constam dos livros das traduções brasileiras mostram apenas a porção ao norte de Cuiabá, nas explorações em direção ao Xingu²4.

\section{Curiosidades gerais}

- Sobre a reação dos cuiabanos a um comentário particular de von den Steinen:

Avaliando a cultura pela extensão e perfeição com que é explorada a natureza que circunda o homem, não se pode em absoluto dizer que era baixo o nível cultural dos nossos índios. Caçavam e pescavam com arco e flecha; pescavam com redes, cestas e nassas; tinham no rio as suas grades de varetas para prender o peixe; atravessavam a corrente com cercas e blocos, barravam braços de lagoas; derrubavam, com grande esforço, vastas extensões de mato; construíam casas vistosas, acumulando novas ricas provisões, e enchendo-as com os variados produtos de sua habilidade de artífices; enfeitavam-se com muitos ornatos multicolores e ornamentavam todos os utensílios com desenhos engenhosos. Se os Cuiabanos, furiosos, lançaram contra mim uma infinidade de artigos de jornal, acusando-me de ter firmado que os silvícolas do Xingu têm residências mais limpas e melhores do que muitos Matogrossenses, quero, sem comparar as causas, acrescentar, para tranquilizá-los, que também na velha Europa há inúmeras aldeias, tanto nas montanhas como na costa, em que a vida é mais pobre e primitiva do que no Culiseu ${ }^{25}$.

- Sobre as formas de comunicação dos índios do Xingu:

De todos os autores da vasta bibliografia sobre os índios xinguanos é von den Steinen que nos brinda com a mais fidedigna reprodução das intermináveis narrativas vespertinas da roda de fumantes seniors, descrevendo detalhadamente o frequente uso da repetição, onomatopéia, entonação e gesticulação como recursos discursivos. O trecho seguinte é parte de um relato de viagem aos índios Bacairi, documentado por von den Steinen ${ }^{26}$ :

${ }^{24}$ COELHO, Vera Penteado. Op. cit.

${ }^{25}$ STEINEN, Karl von den. Op. cit., 1940. p. 255.

${ }^{26}$ VOTRE, Sebastião Josué et alii. Anthony Julius Naro e a lingüística no Brasil: uma homenagem acadêmica. São Paulo: 7Letras, 2008. 
Primeiro se senta na canoa, “pépi”, e se rema, rema 'pépi, pépi, pépi' — rema-se com remos mergulhados, à esquerda, à direita, e se chega a uma corredeira, bububu... De que altura ela se precipita: a mão desce um degrau com cada bu, bu, e como as mulheres se amedrontam e choram: 'pekóto ah, ah, ah (...)! Então a pépi precisa ser empurrada - um violento chute em direção ao solo - através das pedras, com que gemido, e os 'mayáku' os cestos precisam ser transportados por terra, com esforço -1,2,3 vezes o locutor bate no seu ombro esquer-do. Mas entra-se novamente na canoa e se rema 'pépi, pépi, pépi'. Longe, longe - a voz flutua ih (...) tão longe, ih (...) e a boca afunilada mostra a direção no céu, ih (...), enquanto a cabeça é forçada para trás. Entrementes o sol se põe: a mão esticada ao máximo e descreve um arco para oeste e aponta para o ponto do céu onde está o sol, quando se chega — lá... a — ao porto. Aí estamos com os: 'Bakairí, Bakairí, Bakairi !' 'Kúra, Kúra!' e aqui seremos re-cebidos (...). ${ }^{27}$.

O desenho é igualmente um código comunicativo bastante difundido entre os xinguanos. Os desenhos na areia "são como as palavras, sobretudo uma forma de comu-nicação"28, Diz-nos von den Steinen, ao estudar a geografia do rio Kuliseu com os índios: "O rio era desenhado na areia, as tribos eram enumeradas e localizadas com grãos de mi1ho"29. Ademais, atém do seu cunho ilustrativo, o desenho tem para o índio xinguano função epistolar, conforme demonstra o relato seguinte:

Um dia, ao voltarmos, nossa canoa passou por uma praia, por onde já haviam passado nos-sos acompanhantes indígenas; para nossa surpresa vimos aí dois peixes desenhados na areia que Antonio declarou serem matrinchãs. Fizemos uma parada e pescamos, também matrinchãs! Era como se a palavra estivesse escrita ali e o convite transmitido intencionalmente a Antonio, para que aí igualmente tentasse a sorte ${ }^{30}$.

\section{- Comparação entre os índios do Xingu e os bororos de Teresa Cristina}

Quando visitou colônia Teresa Cristina, impressionado com a degradação dos índios bêbados e dependentes, von den Steinen traçou uma comparação com o que tinha visto no $\mathrm{Xingu}^{31}$ :

[...] parece que a vida no Culiseu (Xingu) difere essencialmente da aldeia bororo. Ali, morava-se em bons ranchos de família; aqui possuía cada casal com filhos uma

\footnotetext{
${ }^{27}$ STEINEN, Karl Von den. Op. cit.

${ }^{28}$ Idem, p. 246.

${ }^{29}$ Idem.

${ }^{30}$ Idem, p. 247/8. VOTRE, Sebastião Josué. Op. cit.

${ }^{31}$ COELHO, Vera Penteado. Op. cit.
} 
pequena e miserável choupana; ali os solteiros eram a exceção; aqui a maioria; ali, os homens que viviam em monogamia tinham a sua casa de música, onde não entrava mulher alguma e que servia para as assembléias e danças, e onde, porém, somente se trabalhava quando era preciso fabricar adornos festivais; aqui, eram levadas à força para o ranchão dos homens as raparigas que caíam na posse de vários companheiros, e o trabalho regular de armas e utensílios era feito no ranchão dos homens. Entre os bororos, a vida familiar era manifestamente uma conquista exclusiva dos mais velhos e dos mais fortes ${ }^{32}$.

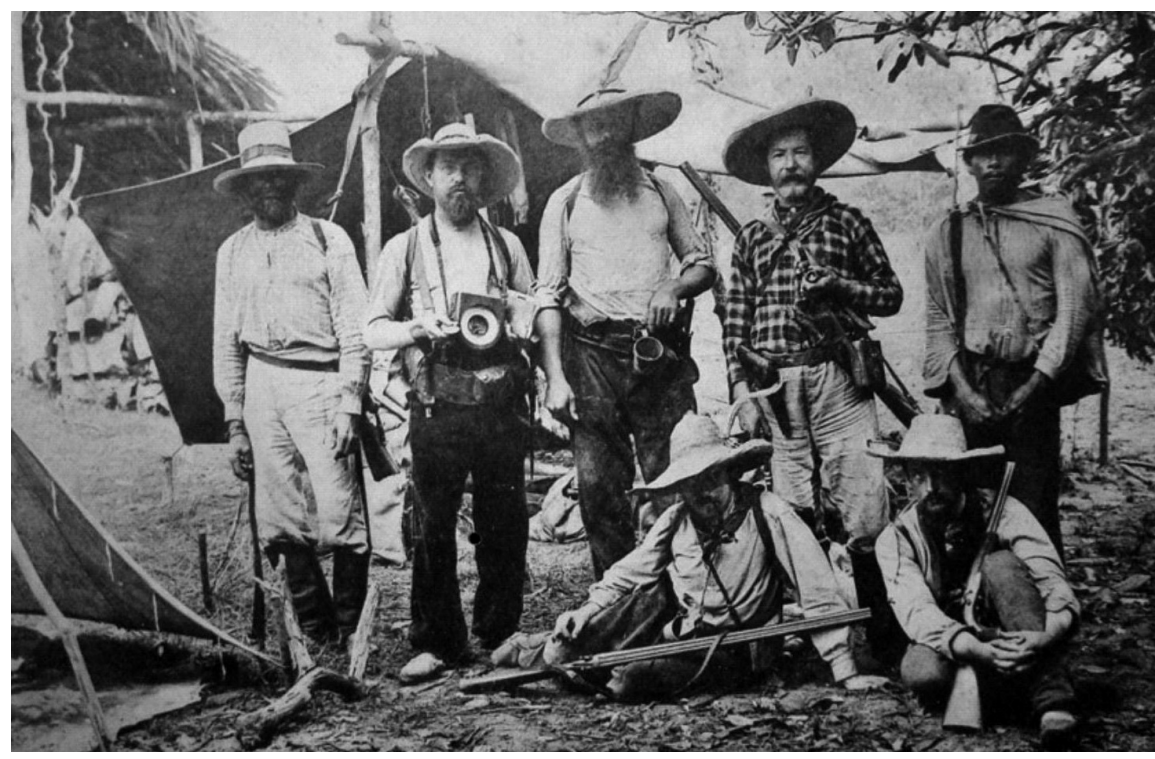

Foto da Expedição na segunda viagem ao Xingu, com Karl von den Steinen ao centro e Peter Vogel à sua esquerda (1887).

${ }^{32}$ STEINEN, Karl Von den. Op. cit., 1940. p. 613. 